\title{
Analisis Titer Antibodi Bovine Zona Pellusida 3 (Anti-bZP3) Hasil Induksi Bovine Zona Pellusida 3 (bZP3) pada Kera (Macaca fascicularis)
}

\author{
Maris Kurniawati ${ }^{1}$, Sutiman B. Sumitro ${ }^{2}$, Aulanni'am ${ }^{2 *}$ \\ ${ }^{1}$ Program Pasca Sarjana Universitas Brawijaya Malang \\ ${ }^{2}$ Fakultas MIPA Universitas Brawijaya Malang
}

\begin{abstract}
Abstrak
Zona pellusida 3 merupakan molekul glikoprotein yang berfungsi sebagai reseptor primer spermatozoa dalam proses fertilisasi. Bovine zona pellusida 3 (bZP3) dapat dikembangkan sebagai target antigen untuk vaksin imunokontrasepsi. Efektivitas kerja antibodi sangat dipengaruhi oleh titer antibodi. Tujuan dilakukan penelitian ini adalah mengetahui profil titer antibodi bovine zona pellusida 3 (anti-bZP3) hasil induksi bovine zona pellusida 3 (bZP3) pada kera (Macaca fascicularis). Imunisasi bZP3 pada kera (Macaca fascicularis) dilakukan secara sub kutan (SC) menggunakan CFA (Complete Freund's Adjuvant) untuk imunisasi pertama dan IFA (Incomplete Freund's Adjuvant) untuk imunisasi booster 1 dan booster 2. Serum dipanen sebanyak 4 kali setelah booster 1 dan 2 . Hasil analisa menunjukkan berat molekul anti-bZP3 dari kera adalah $160 \mathrm{kDa}$. Titer naik mulai minggu ketiga hingga kelima dan turun lagi setelah minggu keenam setelah imunisasi pertama (minggu pertama hingga keempat pasca booster pertama) dan titer naik kembali pada minggu ke tujuh hingga kesembilan serta turun pada minggu ke sepuluh setelah imunisasi pertama (minggu pertama hingga ke empat pasca booster kedua). Titer antibodi tertinggi dicapai pada minggu kesembilan pasca imunisasi pertama atau minggu ketiga pasca booster kedua.
\end{abstract}

Kata kunci: bZP3, imunokontrasepsi, Macaca fascicularis, zona pellusida

\section{Abstract}

Pellucida Zone 3 is a glycoprotein molecule that functioned as the primary receptor of spermatozoa in the fertilization process. Bovine zona pellucida 3 (bZP3) can be developed as an antigen target for vaccine immunocontraception. Effectiveness of the antibody strongly influenced by the antibody titer. The purpose of this study was to determine the profile of bovine anti-bZP3 titers from the induction of bZP3 in monkeys (Macaca fascicularis). Immunization of bZP3 in monkeys conducted via sub-cutaneous (SC) using CFA (Complete Freund's Adjuvant) for the first immunization and IFA (Incomplete Freund's Adjuvant) for immunization booster 1 and booster 2 . Serum harvested 4 times after the booster 1 and 2 . The analysis shows the molecular weight of monkey's anti-bZP3 is $160 \mathrm{kDa}$. Titer rise began at the third until the fifth week and decrease again after the sixth week after the first immunization (first to fourth week after the first booster) and titers rose back in seventh to ninth week and decrease in tenth weeks after the first immunization (first to four week after the second booster). The highest antibody titers achieved in the ninth week after the first immunization or three weeks after the second booster.

Keywords: bZP3, immunocontraception, Macaca fascicularis, zona pellucida

\section{PENDAHULUAN}

Fertilisasi merupakan proses biologi dasar yang melibatkan interaksi sel-sel sperma dan selsel telur. Metode kontrasepsi dapat dilakukan dengan cara mencegah fertilisasi. Fertilisasi pada mamalia melibatkan bagian oosit yang disebut zona pellusida (ZP) yaitu suatu matrik ekstravaskuler yang menyelubungi oosit dan mempunyai fungsi penting dalam proses fertilisasi dan tahap awal perkembangan embrionik [1].

\footnotetext{
* Alamat korespondensi:

Aulanni'am

Email : aulanibiochem@yahoo.com

Alamat : Program Pasca Sarjana Universitas Brawijaya Malang
}

Rekayasa penghambatan fertilisasi dapat dilakukan dengan cara mengganggu fungsi reseptor sperma yang ada pada permukaan zona pellusida. ZP dari spesies yang heterolog menimbulkan reaksi imun yang kuat dan antibodi zona pellusida (anti-ZP) dapat menghambat fertilisasi [2]. Hal ini merupakan dasar pendekatan imonologi untuk menghasilkan vaksin kontrasepsi yang aman, ekonomis dan reversibel [3]. Hanya ada dua jenis glikoprotein yang berperan dalam proses fertilisasi yaitu ZP2 dan ZP3. ZP3 selain berperan serta sebagai reseptor primer spermatozoa juga dapat menginduksi reaksi akrosom, sedangkan ZP2 berperan sebagai reseptor sekunder untuk menjaga terikatnya sperma [4]. 
Menurut Bagavant et al. [5] hasil studi menggunakan ZP sebagai imunogen ternyata menimbulkan antibodi dan dapat mencegah fertilisasi secara in vivo, tetapi diikuti oleh kerusakan ovarium mulai dari primordial volikel sampai volikel yang telah berkembang. Namun hal ini dapat diminimalisasi dengan pemberian imunisasi ZP3 murni. Penelitian yang dilakukan Sumitro dan Aulanni'am [6] telah menetapkan bahwa bovine ZP3 (bZP3) sebagai antigen spesifik yang diisolasi dari oosit sapi dapat menghambat fertilisasi yang bersifat reversibel dan efektif dalam merangsang terbentuknya antibodi bZP3 (anti-bZP3). Titer antibodi sangat dipengaruhi oleh konsentrasi antigen serta spesies hewan.

Bagavant et al. [5] melaporkan bahwa antigen zona pellusida efektif digunakan untuk imunokontrasepsi dalam berbagai jenis hewan. Bovine zona pellusida digunakan sebagai antigen karena antibodi yang dihasilkan mempunyai kemampuan yang cukup besar bereaksi silang dengan zona pellusida spesies mamalia seperti tikus dan kelinci. Efek anti fertilitas dari imunisasi aktif dengan antigen bZP3 telah ditunjukkan pada beberapa model hewan. Dalam penelitian ini akan dilakukan induksi bZP3 berbasis vaksin imunokontrasepsi pada hewan coba dari spesies anggota ordo primata yaitu kelompok kera (Macaca fascicularis) yang diperkirakan lebih mendekati manusia. Penelitian ini bertujuan untuk mengetahui profil titer antibodi bovine zona pellusida 3 (anti-bZP3) hasil induksi bovine zona pellusida 3 (bZP3) pada kera (Macaca fascicularis).

\section{METODOLOGI}

\section{Tempat Penelitian}

Penelitian dilakukan di laboratorium Biologi Molekuler dan Laboratorium Biokimia, Jurusan Kimia, Fakultas Matematika dan Ilmu Pengetahuan Alam, Universitas Brawijaya, serta Laboratorium Biomedik, Fakultas Kedokteran, Universitas Brawijaya, Malang.

\section{Bahan dan Alat Penelitian}

Bahan-bahan yang dipakai dalam penelitian ini meliputi $\mathrm{NaCl}$ fisiologis 0,9\%, streptomycin, pinicilin, phosphate buffer saline (PBS), phenil metil sulfonil fluoride (PMSF), buffer tris-Cl, SAS $50 \%$, buffer fosfat, PBS-tween 20, blocking buffer, buffer karbonat-bikarbonat, tris buffer saline (TBS) dan $\mathrm{NaOH} 3 \mathrm{M}$.

Alat-alat penelitian yang digunakan dalam penelitian adalah disposable siringe, tabung reaksi, pipet pasteur, cawang petri, mikroskop stereo, eppendorf, sentrifus, freezer, elektroforesis, bunsen, gelas beker, water bath, vortex, $\mathrm{pH}$ meter, selofan, stirer, mikropipet, seker.

\section{Koleksi Ovarium}

Ovarium dicuci dengan $\mathrm{NaCl}$ fisiologis $(0,9 \%)$, kemudian dimasukkan botol yang telah berisi $\mathrm{NaCl}$ fisiologis yang sudah ditambah pinisilin 0,006 gram $/ 100 \mathrm{~mL}$ dan streptomycin 0,001 gram $/ 100 \mathrm{~mL}$ dan sudah dihangatkan dengan suhu $\pm 38^{\circ} \mathrm{C}$. Botol berisi ovarium dimasukkan kedalam termos pendingin kemudian dibawa ke laboratorium paling lambat 5 jam setelah pemotongan. Ovarium dibersihkan dari jaringan lemak dan jaringan ikat kemudian disimpan dalam freezer $\left(-10^{\circ}\right)$ maksimum 3 hari.

\section{Isolasi Oosit}

Oosit didapatkan dengan metode aspirasi. Oosit sapi direndam dalam $\mathrm{NaCl}$ fisiologis $(0,9 \%)$, ovarium diambil dengan pinset. Ovarium diaspirasi dengan menggunakan disposibel siringe $5 \mathrm{~mL}$ dengan ukuran jarum 226x1/2" yang telah diisi dengan PBS dingin $2-4^{\circ} \mathrm{C}$ steril kurang lebih $1 \mathrm{~mL}$. Hasil aspirasi berupa cairan folikel yang sudah dicampur dengan PBS dimasukkan kelubang tabung reaksi steril, kemudian didiamkan selama kurang lebih 20 menit untuk diendapkan. Dua pertiga larutan folikel bagian atas dibuang dengan menggunakan pipet pasteur. Sisanya dicuci dengan PBS dingin steril, caranya dengan menyemprotkan PBS dengan kuat ke dasar tabung selanjutnya diendapkan \pm 20 menit, perlakuan ini dilakukan sebanyak tiga kali.

Cairan folikel yang sudah dicuci tersebut dimasukkan ke dalam cawan petri steril berdiameter $10 \mathrm{~cm}$. Cairan folikel diamati dibawah mikroskop stereo, oosit dipilih yang gundul (kualitas KO) dan dipindahkan dalam cawan petri steril berisi PBS. Oosit dicuci dengan PBS sebanyak 3 kali dengan cara memindahkan oosit dengan pipet pasteur ke dalam cawang petri steril yang telah berisi PBS.

\section{Isolasi Bovine Zona Pellusida}

Oosit yang sudah dikumpulkan dipecah dengan cara disedot dan ditiup menggunakan pipet pasteur yang berdiameter $8 \mu \mathrm{m}$ di dalam larutan PBS yang telah ditambah 0,05 mM PMSF. Setelah itu bZP dicuci dengan PBS dingin $\left(2-4^{\circ} \mathrm{C}\right)$ steril, dengan cara memindahkan bZP ke dalam cawan petri steril yang sudah berisi PBS. Selanjutnya bZP dipindah ke dalam larutan PBS. bZP dimasukkan kedalam eppendorf yang berisi 
PBS dengan pipet pasteur sambil dihitung jumlahnya, kemudian disentrifus dengan kecepatan $3000 \mathrm{rpm} 4^{\circ} \mathrm{C}$ selama 30 menit. Supernatan dibuang, dikeringkan kemudian ditambah $20 \mathrm{mM}$ Tris-Cl $20 \mu \mathrm{l}$. bZP disimpan dalam freezer suhu $-10^{\circ} \mathrm{C}$ dan siap digunakan sebagai bahan isolat $b Z \mathrm{P} 3$.

\section{Isolasi Zona Pellusida 3}

Bahan isolat bZP ditambah RSB (1:1) kemudian dipanaskan pada suhu $100^{\circ} \mathrm{C}$ selama 3 menit. Sampel selanjutnya dimasukkan sumuran gel yang sebelumnya telah disiapkan. Running dilakukan pada tegangan $200 \mathrm{~V}$ dan arus $40 \mathrm{~mA}$ dengan konstan arus. Gel hasil elektroforesis kemudian dipotong pada daerah $77 \mathrm{kDa}$ dan dilanjutkan dengan elektroelusi.

Gel yang telah dipotong dimasukkan dalam selofan yang telah berisi buffer fosfat 0,05 M sebanyak $1 \mathrm{~mL}$. Elektroelusi dilakukan pada suhu $4^{\circ} \mathrm{C}$ semalam dengan tegangan $250 \mathrm{~V}$ dan arus 20 $\mathrm{mA}$ konstan arus. Setelah dielektroelusi semalam buffer fosfat diambil dan dimasukkan ependorf. Etanol dingin dimasukkan dengan perbandingan 1:1 dan dihomogenkan. Selanjutnya, homogenat disentrifuge dengan kecepatan 6000 rpm selama 5 menit. Etanol dibuang dan didapatkan presipitat $b Z$ Z3. Prespitat dilarutkan pada buffer tris-Cl 20mM sebanyak 600 mikroliter. Sampel bZP3 disimpan pada freezer suhu $-10^{\circ} \mathrm{C}$ dan siap digunakan untuk imunisasi.

\section{Imunisasi dengan bZP3}

Imunisasi pertama dilakukan pada kelompok hewan coba dengan menambah $300 \mu \mathrm{l} b \mathrm{ZP} 3$ ke dalam Complete Freund's Adjuvant. Injeksi dilakukan dibagian subkutan pada beberapa sisi. Imunisasi kedua dilakukan dengan menambah $300 \mu \mathrm{L}$ bZP3 ke dalam Incomplete Freund's Adjuvant yang disebut booster I. Kemudian dilakukan pengambilan darah dan booster II. Kemudian dilakukan pengambilan darah lagi.

\section{Isolasi Serum dari Hewan Coba}

Darah yang telah didapat sesuai masa inkubasinya didiamkan selama 10 menit pada suhu ruang darah disentrifugasi dengan kecepatan 1500 rpm pada suhu ruang selama 20 menit. Supernatan sebagai serum dipindahkan ke dalam eppendof dan disimpan pada suhu $-2^{\circ} \mathrm{C}$ untuk selanjutnya dilakukan purifikasi.

\section{Purifikasi Anti bZP3 dari Serum}

Serum ditambah dengan SAS 50\% dengan pertandingan 1:1 kemudian dihomogenkan dengan vortex. Selanjutnya diinkubasi pada suhu $4^{\circ} \mathrm{C}$ selama beberapa menit. Supernatan dibuang, presipitat ditambah dengan SAS 50\% (10 kali volume pelet), kemudian dihomogenkan dengan menggunakan vortex. Selanjutnya disentrifugasi dengan kecepatan $3000 \mathrm{rpm}$ pada suhu $4^{\circ} \mathrm{C}$ selama 30 menit. Presipitat ditambah dengan 0,05 M buffer fosfat $\mathrm{pH} 7$ dan didialisis semalam pada suhu $4^{\circ} \mathrm{C}$.

\section{Pengukuran Titer Anti-bZP3}

Anti-bZP3 yang dihasilkan dikarakterisasi berdasarkan nilai titer antibodi dengan teknik ELISA (Enzyme Linked Immuno Sorbant Assay) dengan metode indirect ELISA.

Antigen ZP3 dengan kadar $1 \mu \mathrm{g} / \mathrm{ml}$ dilarutkan dalam carbonat bicarbonate (coating buffer) dimasukkan dalam mikroplate sebanyak $50 \mu \mathrm{l}$ tiap well. Selanjutnya diinkubasi pada $4^{\circ} \mathrm{C}$ selama semalam kemudian mikroplate dicuci dengan PBS/tween 20 empat kali. Anti-bZP3 (antibodi primer) dilarutkan dalam blocking buffer BSA $1 \%$ dengan seri pengeceran 1/50, 1/100, 1/200, $1 / 400$ kemudian dimasukkan mikroplate masingmasing $50 \mu \mathrm{l}$ tiap well. Kemudian diinkubasi pada suhu ruang selama 2 jam. Mikroplate dicuci lagi dengan PBS/tween 20 empat kali. Selanjutnya anti-human IgG berlabel alkaline fosfatase dilarutkan dalam PBS/tween 20 dengan pengeceran 1/1000 dimasukkan mikroplate sebanyak $50 \mu \mathrm{l}$ tiap well, kemudian diinkubasi pada suhu ruang 1 jam. Mikroplate dicuci dengan PBS/tween 20 sebanyak empat kali kemudian substrat pNPP dalam etanolamin $10 \%$ dimasukkan dalam mikroplate masing-masing sebanyak $50 \mu \mathrm{l}$ tiap well. Selanjutnya diinkubasi pada suhu ruang 30 menit dalam ruang gelap, ditambah dengan $\mathrm{NaOH} 3 \mathrm{M}$ sebanyak $50 \mu \mathrm{l} /$ well. Titer diukur dengan ELISA reader dengan panjang gelombang $405 \mathrm{~nm}$.

\section{Analisa Antibodi Zona Pellusida Elektroforesis SDS-PAGE}

Antibodi zona pellusida ditambah dengan RSB (1:1) kemudian dipanaskan pada suhu $100^{\circ} \mathrm{C}$ selama 3 menit. Sampel selanjutnya dimasukkan sumuran gel yang sebelumnya telah disiapkan. Running dilakukan pada tegangan $150 \mathrm{~V}$ dan arus $30 \mathrm{~mA}$ dengan konstan arus. Selajutnya gel dikeluarkan dan dilakukan pewarnaan hingga terlihat band-band yang berwarna ungu.

\section{Dot Blotting}

Antigen diencerkan dalam PBS natrium azida $1 \%$ (1:4). Antigen yang telah diencerkan, 
diteteskan pada membran nitrosellulose yang telah dibasahi dengan PBS (terangkai pada alat dot blotter) dan di degas selama 30 menit.

Membran yang telah mengikat antigen dibloking dengan PBS skim milk 5\% selama 1 jam sambil digoyang. PBS skim milk dibuang kemudian dicuci dengan PBS/tween 20 sebanyak 3 kali. Kemudian diinkubasi dalam serum (antibodi primer) yang telah diencerkan dengan PBS skim milk $1 \%$ selama 2 jam sambil digoyang.

Membran + antigen + antibodi primer dicuci dengan PBS/tween 20 sebanyak 3 kali. Kemudian di inkubasi dalam anti-human IgG Alkaline Phosphatase (AP) Conjugated yang telah diencerkan dalam PBS selama 1 jam sambil digoyang. Kemudian membran dicuci dengan PBS/tween 20 sebanyak 3 kali, dan di inkubasi dalam Subtract Western Blue selama 3 menit dalam ruang gelap. Reaksi dihentikan dengan menambah akuades dan membran dikeringkan. Pada membran akan tampak noda berwarna ungu.

\section{Western Blotting}

Western blotting merupakan kelanjutan dari elektroforesis. Gel hasil elektroforesis dicuci dengan akuades kemudian direndam pada blotting buffer. Kertas saring juga direndam dalam blotting buffer. Selanjutnya disusun sandwich dengan urutan: kertas saringmembran PVDF, gel hasil elektroforesis-kertas saring dan dilakukan transfer dengan tegangan konstan $15 \mathrm{~V}$ dan arus kurang dari 0,35 A semalam. Membran diblok dengan 5\% nonfat milk pada PBST selama 1 jam dan diseker. Kemudian dicuci dengan PBST $3 \times 5$ menit. Inkubasi antibodi primer semalam. Selanjutnya dicuci dengan TBS $3 \times 5$ menit. Inkubasi antibodi sekunder selama 1 jam pada temperatur ruang. Setelah itu dicuci dengan PBST $3 \times 5$ menit. Ditambahkan substrat untuk blotting pada ruang gelap dengan temperatur ruang dan dibiarkan semalam hingga terlihat warna band.

\section{Spektrofotometri UV-Vis}

Masing-masing serum antibodi yang telah dipurifikasi dilarutkan dalam buffer phosphat $0,05 \mathrm{M}$ kemudian dianalisis dengan spektrofotometer UV-Vis pada panjang gelombang 260 $\mathrm{nm}$ dan $270 \mathrm{~nm}$. Selanjutnya profil spektra dari setiap serum dianalisis.

\section{HASIL DAN PEMBAHASAN}

Imunisasi Bovine Zona Pellusida 3 Pada Kera

Anti-bZP3 diperoleh dengan cara imunisasi bZP3 pada kelompok kera. Imunisasi dilakukan dengan penambahan Complete Freund's Adjuvant (CFA) pada $300 \mu \mathrm{ll}$ ZP3 dengan perbandingan 1:1 dilanjutkan dengan booster 1 dan booster 2 menggunakan $300 \mu \mathrm{l}$ ZP3 dan Incomplete Freund's Adjuvant (IFA) dengan perbandingan 1:1. Kadar protein yang digunakan imunisasi sebesar $728 \mu \mathrm{g} / 200 \mu \mathrm{l}$ pelarutnya. Persyaratan yang harus dimiliki oleh antigen adalah melebihi kadar protein $300 \mu \mathrm{g} / 200 \mu \mathrm{l}$ pelarutnya. bZP3 yang telah diinduksikan dalam kera telah memenuhi syarat sebagai antigen. Bagavant et al. [5] telah melakukan imunisasi pada kera dari spesies Macaca radiata dengan menggunakan porcine zona pellusida 3 sebanyak $100 \mu \mathrm{g}$ pZP3 dan mampu menginduksi sintesis anti-pZP3.

\section{Penentuan Berat Molekul Antibodi bZP3}

Penentuan berat molekul dilakukan dengan menggunakan metode Sodium Dodesil SulfatPoliakrilamid Gel Elektroforesis (SDS-PAGE).

Hasil elektroforesis serum kera menunjukkan bahwa ada pola pita yang berbeda antara serum kontrol dan serum kera perlakuan. Perbedaan tersebut dapat dilihat dari pita pada 158,6-162,4 kDa yang tidak terdapat pada kontrol. Rata-rata berat molekul dari anti-bZP3 dari serum kera adalah $160 \mathrm{kDa}$. Pita dengan berat molekul tersebut diduga sebagai IgG karena IgG merupakan imunoglobulin yang dominan pada serum darah. Pengambilan darah hingga dalam kurun waktu yang lama (3-10 minggu) hanya mungkin dari Ig G. Ig A berumur 6 hari, Ig D berumur 3 hari, Ig $E$ berumur 2 hari dan Ig $M$ berumur 5 hari.

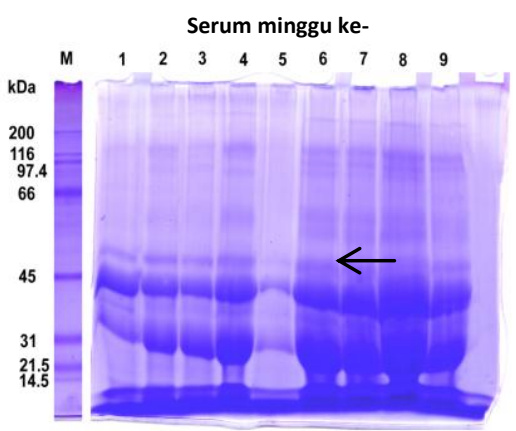

Gambar 1. Elektroforegram dari serum kera pasca imunisasi 1. Keterangan: — : anti-bZP3

Pita hasil elektroforesis mempunyai ketebalan yang berbeda. Hal itu menunjukkan adanya 
perbedaan konsentrasi anti-bZP3. Pita paling tebal terdapat pada minggu ke lima (minggu ke 3 setelah booster 1) dan minggu ke 9 (minggu ke 3 setelah booster 2) setelah imunisasi pertama. Pita yang ditunjukkan setelah booster kedua relatif lebih tebal dibanding setelah booster pertama. Hal ini disebabkan respon imun setelah booster kedua lebih tinggi dari pada setelah booster pertama.

\section{Uji Spesifisitas Antibodi bZP3 dengan bZP3}

Untuk mengetahui spesifisitas antibodi (imunoglobulin) sebagai respon dari imunisasi bZP3 dilakukan dengan menggunakan metode dot blotting dan western blotting yang bersifat semi kuantitatif. Hasil dot blotting memperlihatkan adanya reaksi antigen $b Z P 3$ dengan antibodi terhadap $b Z$ Z3.

Pada kontrol tidak menunjukkan adanya reaksi antigen dengan antibodi. Hal ini berarti kera yang telah diimunisasi dengan bZP3 memberikan respon dengan menghasilkan antibodi terhadap bZP3 dan sifat spesifitas anti$b Z P 3$ terhadap $b Z P 3$.

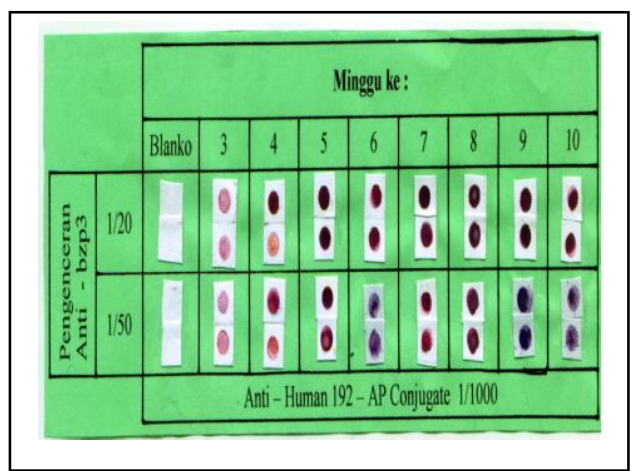

Gambar 2. Uji keberadaan dan pesifisitas bZP3 terhadap anti-bZP3 menggunakan metode dot blotting.

Warna ungu dari hasil pengujian menunjukkan bahwa antigen bZP3 dapat dikenali oleh antibZP3. Warna itu menunjukkan telah terjadi reaksi spesifik antara $b Z P 3$ dengan anti-bZP3 yang difisualisasi dengan penambahan antibodi sekunder yang terlabel oleh alkaline phosphatase (AP) dengan substrat western blue. Pada kontrol tidak menimbulkan warna ungu karena dalam serum hewan kontrol tidak terdapat anti-bZP3.

Pengenceran anti-bZP3 sampai $1 / 50$ masih menunjukkan intensitas yang berbeda pada pemanenan serum yang berbeda. Intensitas warna ungu tertinggi terdapat pada minggu ke lima setelah imunisasi pertama dan minggu ke sembilan setelah imunisasi pertama. Minggu ke lima berarti minggu ke tiga setelah booster pertama dan minggu kesembilan berarti minggu ketiga setelah booster kedua. Selanjutnya pada minggu ketiga setelah imunisasi pertama atau minggu pertama setelah booster pertama warna ungu yang dihasilkan lebih tipis dibandingkan pada minggu keempat dan kelima.

Uji western blotting dipakai untuk melakukan konfirmasi terhadap data dot blotting seperti Gambar 3 dan 4. Intensitas warna ungu hasil western blotting pada Gambar 3 hasil pewarnaan anti-bZP3 minggu ketiga hingga kelima pasca imunisasi pertama terjadi peningkatan intensitas warna ungu tetapi melemah pada minggu ke enam pasca imunisasi pertama. Hal ini juga terjadi pada pewarnaan anti-bZP3 pada minggu 7, 8, 9 pasca imunisasi pertama. Intensitas warna ungu bertambah dari minggu ke 7 hingga ke 9 dan mulai melemah pada minggu 10, sehingga data profil titer antibodi secara kualitatif dapat diketahui. Hasil western blotting menunjukkan perbedaan intensitas warna sebanding dengan konsentrasi anti-bZP3 dimana peningkatan konsentrasi titer terjadi ketika intensitas warna bertambah karena peningkatan intensitas warna menunjukkan komplek antigen-antibodi yang terbentuk semakin banyak.

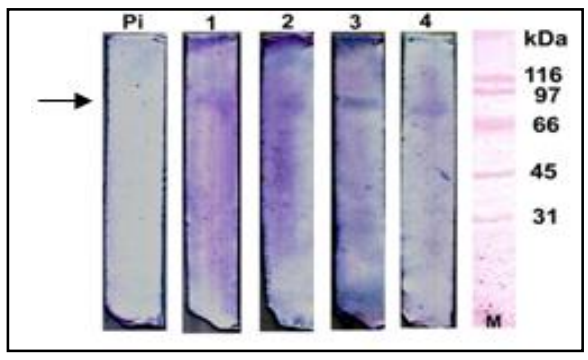

Gambar 3. Uji keberadaan dan Spesifitas bZP3 dari serum kera (Western Blotting) setelah imunisasi pertama.

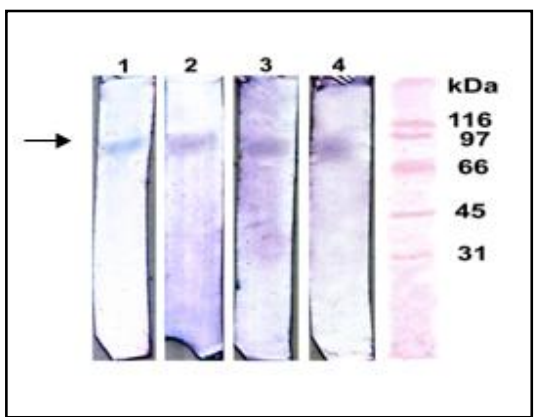

Gambar 4. Uji Keberadaan dan Spesifitas bZP3 terhadap anti - $b Z \mathrm{ZP}$ dari serum kera menggunakan metode western blotting setelah imunisasi pertama.

Keterangan: (M) marker; (1) minggu 7; (2) minggu 8; (3) minggu 9; (4) minggu 10; $\rightarrow$ : Posisi $b Z$ P3 yang dikenali anti-bZP3 dari kera. 
Kemampuan bZP3 dalam menginduksi antibZP3 pada Macaca fascicularis dapat diartikan bahwa apabila dibentuk pada macaca betina dapat menghambat proses fertilisasi.

\section{Analisa Kuantitatif Anti-bZP3 dari Serum Kera dengan Metode ELISA}

Titer anti-bZP3 pada langkah kerja ini diukur berdasarkan nilai absorbansi pada panjang gelombang $405 \mathrm{~nm}$ pada ELISA reader dengan metode Enzyme Linked Immuno Sorbant Assay (ELISA).

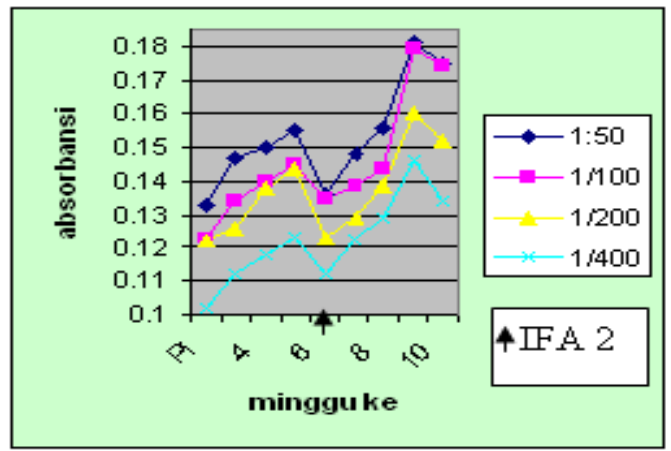

Gambar 5. Analisa Profil Titer anti-bZP3 dari Serum kera hasil Induksi $b Z$ Z3 menggunakan Metode ELISA. Keterangan: Pi: preimun; IFA2: booster kedua $b Z \mathrm{ZP} 3$

Gambar 5 menunjukkan bahwa profil titer anti-bZP3 yang diperoleh dari serum kera yang diinduksi oleh bZP3 meningkat dari minggu ketiga hingga minggu kelima dan menurun pada minggu keenam pasca imunisasi pertama. Titer tertinggi terjadi pada minggu kelima. Hasil pengukuran titer anti-bZP3 yang dipanen pada minggu-minggu pasca booster kedua menunjukkan titer yang lebih tinggi.

Induksi bZP3 akan memberikan respon dengan dihasilkannya anti-bZP3. Tiga ratus mikroliter bZP3 yang diinduksikan ternyata mampu menginduksi anti-bZP3 yang terus meningkat dari minggu ke 3 hingga ke 5 pasca imunisasi pertama, artinya selama tiga minggu bZP3 mampu menginduksi terbentuknya anti$b Z$ P3. Setelah minggu ke 6 titer mengalami penurunan. Booster imunisasi antigen perlu diberikan pada saat titer antibodi yang ditimbulkan sudah rendah. Apabila booster diberikan pada saat titer tinggi maka pemberian boster tidak dapat menginduksi terbentuknya antibodi karena antigen yang masuk akan ditangkap oleh antibodi yang ada. Booster diberikan pada saat titer rendah untuk menginduksi terbentuknya antibodi kembali dan tidak ditangkap oleh antibodi yang diinduksi pada imunisasi sebelumnya. Minggu ke 3 merupakan perhitungan dari pemberian imunisasi pertama. Sedangkan dari pemberian booster berselang seminggu. Hal ini dapat diartikan bahwa pemberian booster kembali diperlukan setelah 4 minggu dari booster sebelumnya. Minggu ke 7 hingga minggu 9 titer mengalami peningkatan dan menurun setelah minggu ke 10. Profil ini sama dengan profil minggu-minggu sebelumnya, dimana puncak tertinggi pada minggu 9 atau minggu ke 3 setelah booster ke 2 .

Hasil pengukuran absorbansi ELISA dengan pengenceran anti-bZP3 1/50,1/100, 1/200 dan $1 / 400$ menunjukkan pola profil titer dari antibZP3 dari serum kera sebanding dengan besarnya pengenceran. Pengukuran titer dengan pengenceran sampai dengan 1/400 masih dapat dibaca profil titernya. Berbagai pengenceran yang telah dilakukan dimaksudkan untuk mengetahui tingkat sensitifitas dari pengukuran titer antibZP3 dengan menggunakan metode ELISA. Sensitifitas tertinggi adalah pengukuran antibodi dengan pengenceran tertinggi.

Hasil ELISA didukung dengan data hasil pengukuran absorbansi dengan spektrofotometer UV-Vis pada panjang gelombang $260 \mathrm{~nm}$ dan $270 \mathrm{~nm}$. IgG dapat diukur dengan spektrofotometer UV-Vis pada panjang gelombang $260-270 \mathrm{~nm}$ sehingga pada penelitian ini pengukuran dengan metode spektrofotometri merupakan data pendukung dari data yang diperoleh dari metode ELISA. Profil titer hasil pengukuran dengan metode spektrofotometri dapat dilihat pada gambar 6. Hal ini sesuai dengan pendapat [7] yang menyatakan bahwa protein yang mempunyai gugus karboksilat dan gugus amina mempunyai serapan maksimum pada panjang gelombang $260 \mathrm{~nm}$.

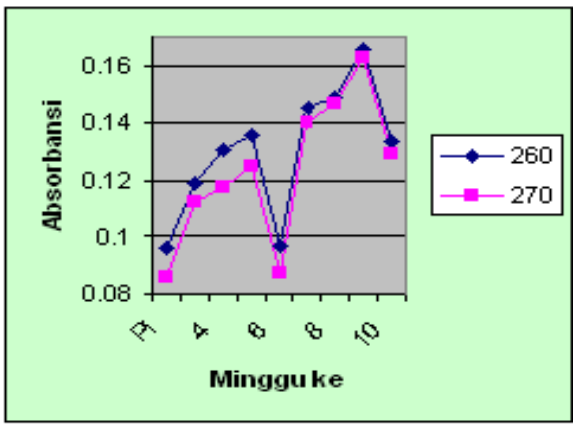

Gambar 6. Penentuan absorbansi anti-bZP3 dari serum kera dengan spektrofotometer UV-Vis dengan $\lambda 260 \mathrm{~nm}$ dan $270 \mathrm{~nm}$. Keterangan: Pi: preimun.

Hasil pengukuran anti-bZP3 dengan metode ELISA mempunyai kesamaan dengan hasil pembacaan dengan spektrofotometri. Titer 
tertinggi terdapat pada minggu kelima setelah imunisasi pertama dan minggu ke sembilan setelah imunisasi kedua. Namun puncak tertinggi titer anti-bZP3 terjadi pada minggu kesembilan pasca imunisasi pertama.

Adapun induksi anti-bZP3 diduga melalui jalur yaitu antigen ditangkap oleh APC (sel dendrit), dan dipresentasikan bersama MHC kelas II yang mengadakan komplek dengan dendrite sel. Sinyal dibawa oleh $\mathrm{T}$ helper menyebabkan aktivasi $\mathrm{T}$ helper untuk membentuk reseptor $\mathrm{T}$, selanjutnya disekresikan soluble molekul sitokin (IL - 2) yang mengaktivasi sel-sel yang lain seperti aktivasi pada sel B. Dalam plasma limfosit B mensekresikan Ig $G$ sebagai anti-bZP3 dan pada mamalia betina anti-bZP3 akan menuju pada target sel yaitu sel ovarium [6].

Molekul ZP3 dari satu spesies dengan spesies yang lain terdapat bagian yang bersifat homolog. Menurut Carino et al. [8] ZP3 babi mempunyai homologi dengan manusia sebesar $74 \%$. Homologi ini juga terjadi pada mamalia yang lain. Antara sapi dengan kera juga ada sifat homologi tersebut maka pada saat dilakukan imunisasi pada kera maka antibodi yang dihasilkan akan mengenali bZP3 pada kera. Selanjutnya akan terjadi interaksi dari ZP3 hewan yang diinduksi dengan anti-bZP3 hasil induksi $b Z P 3$.

\section{KESIMPULAN DAN SARAN Kesimpulan}

Dari hasil penelitian dapat disimpulkan bahwa induksi bovine zona pellusida 3 (bZP3) pada kera (Macaca fascicularis) mampu mensintesis anti bovine zona pellusida 3 (anti-bZP3). Karakteristik anti-bZP3 hasil induksi bZP3 pada kera mempunyai berat molekul sebesar 160 kDa. Data imunobloting menunjukkan bahwa profil titer antibodi bZP3 menunjukkan peningkatan dari minggu 3 hingga minggu ke 5 setelah imunisasi pertama dan menurun setelah minggu ke 6 (minggu pertama hingga ke 4 setelah booster 1). Titer kembali meningkat setelah booster 2 dan mencapai puncak pada minggu ke 9 dan turun kembali pada minggu ke 10 setelah imunisasi pertama (minggu pertama hingga ke 4 setelah booster 2). Titer pada minggu ke 5 ratarata sebesar 0,15 dan pada minggu ke 9 rata-rata sebesar 0,17 dengan metode ELISA pada pengeceran anti-bZP3 1/100.

\section{Saran}

Masih perlu dilakukan penelitian lebih lanjut tentang peranan bZP3 sebagai calon imuno- kontrasepsi pada kelompok kera (Macaca fascicularis).

\section{DAFTAR PUSTAKA}

[1] Sinowatz F. 2002. Kumpulan Abstrak PIN 2002 PAAl: New Concepts in Sperm-Oocyte, Interaction and Immunocontraception. University of Munich. Germany.

[2] Hasegawa A., Yamakasi N., Inove M., Koyama K., dan Isojika S. 1995. Analysis of an epitope sequence recocniced by monoclonal antibody Mab-5H4 againts a Porcine Zona Pellucida Glycoprotein ( $p$-ZP4) that block fertilization. Journal of Reproduction and Fertility. 105 (2): 295-302.

[3] Gwatkin R.B.L. 1982. Receptor for sperm on the mammalian ovum. In Hafez E.S.E. and Semm K. (Eds). In Vitro fertilization and embryo transfer. A.R. Liss. New York.

[4] Bauksin A.R., Franken D.R., Eberspacher U., dan Domes P. 1999. Characterization of Human Zona Pellucida Glycoprotein. Molecular Human Reproduction. 5 (6): 534540.

[5] Bagavant H., Thillai-Koothan P., Sharma M.G., Talwar G.P., dan Gupta S.K. 1994. Antifertility effect or Porcine Zona Pellucida3 immunization using permissible adjuvant in female Bonnet Monkey (Macaca radiata): Reversible, effect on follicular development and hormonal profiles. Journal of Reproduction and Fertility. 102: 17-25.

[6] Sumitro S.B. dan Aulanni'am. 2002. Zona Pellucida 3 (ZP3) has proper biochemical properties to be considered as candidate antigen for immunocontraceptive vaccine. Reprotech. 1 (1). 51-53.

[7] Hendayana S.A., Kadarohmah, Sumarna A.A., dan Supriatna A. 1994. Kimia Analitik Instrumen. IKIP Semarang Press. Semarang.

[8] Carino C.L.D. and Mendez I. 2001. Zona pellucida antigens in the human ovum: its importance in contraceptive strategies. Revista de Investigacion Clinica. 53 (2): 174180. 